JIBEKA

Jurnal IImiah Bisnis dan Ekonomi Asia

ISSN 2620-875X (Online) ISSN 0126-1258 (Print)

http://jurnal.stie.asia.ac.id

Hal. 01-06

\title{
Pengaruh Pembiayaan dan Efisiensi Operasi Terhadap Pencapaian Laba Pada BPR Syariah di Jawa Timur
}

\author{
Rifki Hanif \\ Program Studi Manajemen, Sekolah Tinggi Ilmu EKonomi Asia Malang \\ Alamat e-mail: rifki.hanif@asia.ac.id \\ Raisa Fitri \\ Program Studi Manajemen, Sekolah Tinggi Ekonomi Asia Malang \\ Alamat e-mail: raishav3@gmail.com
}

\begin{abstract}
This study aims to determine the effect of Operating Costs and Income and Loan Asset Ratio to Achievement of Profit in Islamic Rural Banks in East Java. The existence of Sharia Banking is increasingly recognized by the government as shown by the increasing number of banks conducting business based on sharia principles in 2011. In 2011, banking performance showed positive growth supported by high profitability, and other financial indicators that showed positive growth, where growth in 2011 is relatively higher. Total assets of BPRS increased by 28.21\% from Rp. 2.73 trillion (2010) to Rp. 3.50 trillion (in 2011), (Bank Indonesia, 2011). This study uses multiple regression analysis model. And the type of data used is secondary data taken through Bank Indonesia Report.
\end{abstract}

Keywords: Operating and Revenue Costs, Loan Asset Ratio, Profit Achievement, Sharia Rural Banks

\begin{abstract}
Abstrak
Penelitian ini bertujuan untuk mengetahui pengaruh Biaya dan Pendapatan Operasional dan Loan Asset Ratio terhadap Pencapaian Laba pada BPR Syariah di Jawa Timur. kinerja perbankan menunjukkan perkembangan yang positif yang didukung oleh profitabilitas yang cukup tinggi, dan indikator keuangan yang lain yang menunjukkan pertumbuhan positif, dimana pertumbuhan ditahun 2011 relatif lebih tinggi. Total asset BPRS meningkat sebesar 28,21\% dari Rp. 2,73 triliun (2010) menjadi Rp. 3,50 triliun (tahun 2011), (Bank Indonesia, 2011). Penelitian ini memakai model analisis regresi berganda. Dan jenisdata yang digunakan adalah data sekunder yang diambil melalui Laporan Bank Indonesia.
\end{abstract}

Kata Kunci: Biaya dan Pendapatan Operasional, Loan Asset Ratio, Pencapaian Laba, BPR Syariah 


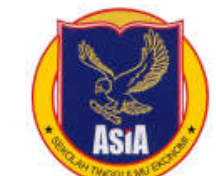

JIBEKA

Jurnal IImiah Bisnis dan Ekonomi Asia

ISSN 2620-875X (Online) ISSN 0126-1258 (Print)

http://jurnal.stie.asia.ac.id

Hal. 01-06

\section{Pendahuluan}

Eksistensi Perbankan Syariah semakin diakui oleh pemerintah, terbukti dengan dikeluarkan peraturan perundangan baru tentang bank syariah undang-undang nomor 21 tahun 2008 yang mengatur secara khusus sistem Perbankan Syariah di indonesia (Rahma, 2016). Selain itu eksistensi ini juga ditunjukkan oleh meningkatnya Jumlah bank yang melakukan kegiatan usaha berdasarkan prinsip syariah pada tahun 2011. Tahun 2011, kinerja perbankan menunjukkan perkembangan yang positif yang didukung oleh profitabilitas yang cukup tinggi, dan indikator keuangan yang lain yang menunjukkan pertumbuhan positif, dimana pertumbuhan ditahun 2011 relatif lebih tinggi. Total asset BPRS meningkat sebesar $28,21 \%$ dari Rp. 2,73 triliun (2010) menjadi Rp. 3,50 triliun (tahun 2011), (Bank Indonesia, 2011). Bank juga melayani pada sisi penghimpunan dana (funding) maupun penyaluran dana/pembiayaan (financing).

Di sisi penyaluran dana, selama tahun 2011 BPRS masih dapat mempertahankan tingkat bagi hasil yang kompetitif sehingga dapat mempertahankan loyalitas nasabah lama dan menarik nasabah baru. Selain itu, relatif bersaingnya besaran margin pembiayaan. Salah satu alasan kenaikan pembiayaan BPRS adalah ekspansi pembiayaan BPRS yang ditunjukkan oleh FDR. Pembiayaan berbasis jual beli dan bagi hasil masih menjadi pilihan utama transaksi BPRS. Komposisi pembiayaan dengan akad murabahah masih mendominasi dengan porsi sebesar $80,51 \%$. Sementara pembiayaan bagi hasil masih didominasi oleh akad musyarakah dengan pangsa $9,22 \%$ dan akad mudharabah dengan pangsa 2,83\%. Selain itu terdapat perkembangan pembiayaan multi jasa yang cukup baik yaitu sebesar Rp89,23 Miliar. Hal ini menunjukkan bahwa BPRS telah mendapat kepercayaan masyarakat. meningkatnya kepercayaan masyarakat sehingga tingginya pembiayaan yang dilakukan oleh BPRS, BPRS dituntut untuk menilai kemampuanya dalam memenuhi permintaan kredit melalui jaminan sejumlah set yang dimiliki (Ioan to asset rasio). LAR (loan to asset rasio) harus diukur oleh BPRS untuk mengetahui dampaknya terhadap pencapain laba BPRS,. Berdasarkan penelitian terdahulu menjelaskan bahwa LAR berpengaruh positif terhadap ROA karena semakin tinggi kredit yang diberikan maka semakin besar pendapatan bunga yang diperoleh, sehingga tingkat pengembalian aset akan semakin tinggi (Kurnia \& Mawardi, 2012).

Selain kemampuan memberikan kredit, pencapain laba juga bisa dipengaruhi oleh besarnya biaya operasional. Menurut (Mawardi, 2005), BOPO merupakan perbandingan antara total biaya operasi terhadap total pendapatan operasi. Efisiensi operasi dilakukan oleh bank dalam rangka untuk mengetahui apakah bank telah menggunakan semua faktor produksinya dengan tepat guna dan berhasil guna, kondisi ini akan mempengaruhi pencapaian laba BPRS(Harianto, 2017). LAR dan BOPO merupakan suatu variabel yang berhubungan dengan kemampuan pembiayaan dan efisiensi operasi perusahaan.

Berdasarkan uraian diatas maka tujuan penelitian ini adalah untuk mengetahui pengaruh kemampuan pembiayaan (LAR) dan efisiensi operasi yang di proksikan dengan BOPO (Biaya operasional/pendapatan operasional) terhadap pencapaian labapada BPR Syariah di Jawa Timur.

\section{Metode Penelitian}

Karena data yang dibutuhkan adalah data sekunder yang terdapat di Bank Indonesia. Maka Penelitian ini dilakukan di Bank Indonesia Malang Jawa Timur. Sampel peneltian dilakukan secara purposive pada Bank Perkreditan Rakyat Syariah (BPRS) di Jawa Timur yang memiliki data neraca dan laporan laba rugi yang lengkap. Jenis data yang digunakan pada penelitian ini adalah data sekunder yang diambil melalui laporan Bank Indonesia.

Teknik pengumpulan data dalam penelitian ini dilakukan melalui proses dokumentasi data pendukung di Bank Indonesia Malang Jawa Timur. Dan studi pustaka dilakukan dengan cara 


\section{JIBEKA}

Jurnal IImiah Bisnis dan Ekonomi Asia

Asth

ISSN 2620-875X (Online) ISSN 0126-1258 (Print)

http://jurnal.stie.asia.ac.id

Hal. 01-06

mempelajari, mendalami, dan mengutip teori-teori atau konsep-konsep dari sejumlah literatur, baik buku, jurnal, majalah, koran, atau karya tulis lainnya yang relevan dengan topik, fokus atau variabel penelitian

Analisis ini untuk menentukan persamaan regresi yaitu dengan menentukan besarnya nilai konstanta dan koefisiennya. Menurut (Gujarati, 2004) persamaan regresi berganda adalah sebagai berikut.

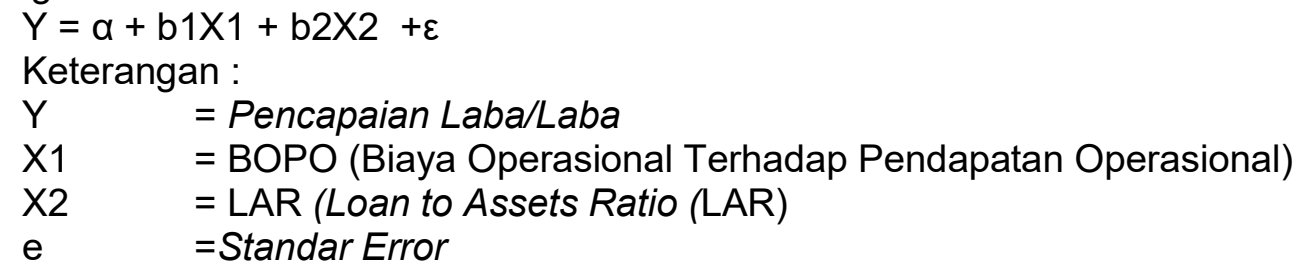

\section{Hasil Dan Pembahasan}

Tabel 1. Hasil Regresi Berganda

\begin{tabular}{|c|c|c|c|c|c|c|}
\hline \multirow{2}{*}{\multicolumn{2}{|c|}{ Model }} & \multicolumn{2}{|c|}{ Unstandardized Coefficients } & \multirow{2}{*}{$\frac{\text { Standardized Coefficients }}{\text { Beta }}$} & \multirow[b]{2}{*}{$t$} & \multirow[b]{2}{*}{ Sig. } \\
\hline & & B & Std. Error & & & \\
\hline \multirow[t]{3}{*}{1} & (Constant) & ,062 & ,680 & & ,091 & ,928 \\
\hline & BOPO &,- 279 & ,387 &,- 167 &,- 562 & ,747 \\
\hline & LAR & 2,265 &, 727 &,- 686 & $3,552^{-}$ &, 001 \\
\hline & $\begin{array}{l}\text { Dependent } \\
\text { Variable: }\end{array}$ & \multicolumn{5}{|c|}{ Pencapaian Laba } \\
\hline & R Square & \multicolumn{5}{|l|}{0,391} \\
\hline
\end{tabular}

Berdasarkan hasil penelitian dengan menggunakan alat uji statistik dapat dirumuskan persamaan regresi linier berganda adalah sebagai berikut:

$$
\text { Y pencapaian laba }=0,062-0,279 \mathrm{BOPO}+2,265 \mathrm{LAR}
$$

Berdasarkan persamaan regresi juga bisa dijelaskan bahwa penurunan nilai rasio BOPO (Biaya operasional dibanding pendapatan operasional) akan menyebabkan perubahan atau meningkatnya pencapaian laba pada BPRS di Jawa Timur. Besar kredit yang diberikan bank perkreditan rakyat dibandingkan dengan besarnya total aset yang dimiliki bank ( loan to assets ratio) atau rasio LAR menunjukkan bahwa peningkatan LAR atau besarnya kredit yang mampu meningkatkan pencapaian laba.

Berdasarkan hasil uji statistic dapat diketahui bahwa secara parsial rasio biaya operasional tidak berpengaruh terhadap pencapaian laba pada BPRS di Jawa Timur, kondisi ini bisa dilihat dari hasil uji $t$ hitung $<t$ tabel $(-0,562<1,6859)$ yang didukung oleh nilai signifikasi sebesar $0,747>0,05)$, sehingga $\mathrm{H} 1$ ditolak. Hasil penelitian ini tidak mendukung penelitian yang dilakukan oleh (Wibowo \& Syaichu, 2013)yang menjelaskan bahwa setiap peningkatan biaya operasional akan berakibat pada berkurangnya laba sebelum pajak dan akhirnya akan menurunkan laba atau profitabilitas (ROA) bank yang bersangkutan. Pada BPRS di Jawa Timur, biaya operasional yang tinggi lebih terjadi pada beban operasional pegawai atau personalia, bukan pada biaya administrasi atau biaya 


\section{JIBEKA}

Jurnal IImiah Bisnis dan Ekonomi Asia

ISSN 2620-875X (Online) ISSN 0126-1258 (Print)

http://jurnal.stie.asia.ac.id

Hal. 01-06

titipan wadiah. Kondisi ini yang menyebabkan tidak ada pengaruh BOPO terhadap pencapaian laba.

Untuk LAR terhadap laba bisa dilihat dari nilai $t$ hitung $>t$ tabel $(3,552>0,642)$ pada tingkat signifikasi $0,001<0,025$ (uji 2 sisi). Hal ini menunjukkan besarnya kredit yang diberikan oleh BPR Syariah di Jawa Timur berpengaruh terhadap pencapaian laba.Hal ini sesuai dengan temuan (Rahayu, Husaini, \& Azizah, 2016) yang menunjukan bahwa kredit yang di berikan BPRS (murabahah, musyarakah, qord, dan lain-lain) berpengaruh secara positif terhadap pencapaian laba. Semakin besar BPRS memberikan kredit pada usaha mikro menengah maka pencapaian laba akan semakin meningkat.

Sementara hasil penelitian secara simultan BOPO dan LAR terhadap pencapaian laba bisa dilihat pada tabel dibawah ini:

Tabel 2. Hasil Uji F test

\begin{tabular}{|l|l|l|l|l|l|l|}
\hline \multicolumn{2}{|c|}{ ANOVA $^{\mathrm{a}}$} \\
\hline \multirow{2}{*}{ Model } & $\begin{array}{c}\text { Sum of } \\
\text { Squares }\end{array}$ & Df & $\begin{array}{c}\text { Mean } \\
\text { Square }\end{array}$ & F & Sig. \\
\hline & Regression & 5,367 & 3 & 1,789 & 7,030 &, $014^{\mathrm{b}}$ \\
& Residual & 16,869 & 38 &, 444 & & \\
\cline { 2 - 9 } & Total & 22,237 & 41 & & & \\
\hline
\end{tabular}

a. Dependent Variable: LABA

b. Predictors: (Constant), BOPO, LAR

Berdasarkan hasil statistic ANOVA dapat diketahui bahwa nilai $\mathrm{F}$ hitung $>\mathrm{F}$ tabel $(4,030>2,85)$ yang didukung tingkat signifikasi 0,14 . Kondisi ini berarti terdapat pengaruh simultan biaya operasional/pendapatan operasional (BOPO) dan LAR terhadap pencapaian laba.

BPRS di Jawa Timur harus mempertimbangkan biaya operasional seperti biaya karyawan/personalia, beban adminstrasi dan umum, beban wadiah serta beban lainnya agar laba yang dicapai BPRS meningkat. BPRS di Jawa Timur mampu mengelola pemberian kredit sebagian besar dalam bentuk pembiayaan mudharobah, murabahah dan musyarakah. Sementara pembiayaan dalam bentuk qord maupun ijaroh pada beberapa BPRS di Jawa Timur cukup kecil.

Hasil uji model antara BOPO dan LAR terhadap Laba menunjukkan bahwa BPRS harus mampu menekan biaya operasional dan mampu meningkatkan kredit serta BPRS harus mampu mengelola manajemen Resiko serta transaksi sesuai dengan syariat) sehingga akan mempengaruhi pencapaian labayang meningkat pada BPRS di Jawa Timur.

\section{IV.Kesimpulan}

Efisiensi operasi dilakukan oleh bank dalam rangka untuk mengetahui apakah bank telah menggunakan semua faktor produksinya dengan tepat guna dan berhasil guna, kondisi ini akan mempengaruhi pencapaian laba BPRS. LAR dan BOPO merupakan suatu variable yang berhubungan dengan kemampuan pembiayaan dan efisiensi operasi perusahaan. Secara parsial, rasio biaya operasional tidak berpengaruh terhadap pencapaian laba pada BPRS di Jawa Timur, yang menunjukan hasil berbeda dibandingkan dengan penelitian (Wibowo \& Syaichu, 2013), (Cut Marliana TA dan Meutia Fitri, S.E, M.M, 2016), dan(Dan, Bank, \& Pratama, 2016). Perbedaan tersebut dimungkinkan karena 


\section{JIBEKA}

Jurnal IImiah Bisnis dan Ekonomi Asia

nst1. ISSN 2620-875X (Online) ISSN 0126-1258 (Print)

http://jurnal.stie.asia.ac.id

Hal. 01-06

perbedaan karakter obyek penelitian, dimana pada penelitian ini, yang menjadi obyek penelitian adalah BPRS (Bank Prekreditan Rakyat Syariah) di Jawa timur bukan Bank Umum Syariah.

Rasio LAR menunjukkan bahwa peningkatan LAR atau besarnya kredit yang mampu meningkatkan pencapaian laba. Hasil temuan ini mendukung atau sesuai dengan temuan dari penelitian (Haq, 2015).

Dari uji model menunjukan peran BOPO dan LAR bahwa BPRS harus mampu menekan biaya operasional dan mampu meningkatkan kredit (membentuk satuan kerja audit internal, ketentuan disclosure dalam bentuk penyajian laporan keuangan yang bisa diakses oleh publik, persyaratan pemilik dan pengurus serta BPRS harus mampu mengelola manajemen Resiko serta transaksi sesuai dengan syariat) sehingga akan mempengaruhi pencapaian labayang meningkat pada BPRS di Jawa Timur.

\section{Daftar Pustaka}

-http. www. bi.go.id./Perbankkan dan laporan Pengawasan Perbankkan (LPP).2011

-SK direktur BI no.32/36/Kep Dir/1999, tentang BPR Syariah.

Undang-Undang no 21 tahun 2008 tentang sistem perbankan syariah di Indonesia.

Cut Marliana TA dan Meutia Fitri, S.E, M.M, A. (2016). Pengaruh Biaya Operasional, Dana Pihak Ketiga Dan Non Performing Finance Terhadap Pertumbuhan Laba Pada. Jurnal Ilmiah Mahasiswa Ekonomi Akuntansi (JIMEKA), 1(1), 247-257.

Dan, O., Bank, U., \& Pratama, R. A. D. I. (2016). Profitabilitas Bank Umum Syariah Di Indonesia.

Gujarati, D. N. (2004). Basic Econometrics. New York. https://doi.org/10.1126/science.1186874

Haq, R. N. A. (2015). Pengaruh Pembiayaan Dan Efisiensi Terhadap Profitabilitas Bank Umum Syariah. Perbanas, 1(November), 107-124.

Harianto, S. (2017). Rasio Keuangan dan Pengaruhnya Terhadap Profitabilitas Pada Bank Pembiayaan Rakyat Syariah. Esensi, 7(1), 41-48. https://doi.org/10.15408/ess.v7i1.4076

Kurnia, I., \& Mawardi, W. (2012). Analisis Pengaruh BOPO, EAR, LAR dan Firm Size Terhadap Kinerja Keuangan. Journal Of Management.

Mawardi, W. (2005). Analisa faktor-faktor yang mempengaruhi kinerja keuangan bank umum di Indonesia (studi kasus pada bank umum dengan total asset kurang dari 1 triliun). Jurnal Bisnis Strategi.

Rahayu, Y. S., Husaini, A., \& Azizah, D. F. (2016). PENGARUH PEMBIAYAAN BAGI HASIL MUDHARABAH DAN MUSYARAKAH TERHADAP PROFITABILITAS ( Studi pada Bank Umum Syariah yang terdaftar pada Bursa Efek Indonesia periode 2011-2014 ). Journal Accounting.

Rahma, Y. (2016). Faktor-Faktor Yang Mempengaruhi Margin Murabahah Bank Syariah Di Indonesia. Akuntabilitas, 9(1), 43-54. https://doi.org/10.15408/akt.v9i1.3584 
Wibowo, E. S., \& Syaichu, M. (2013). Analisis pengaruh suku bunga, inflasi, car, bopo, npf terhadap profitabilitas bank syariah. Diponegoro Journal of Accounting. 